\title{
Ecologic Aspects of Ectopic Populations of Monk Parakeets (Myiopsitta monachus) and Possible Agricultural Consequences ${ }^{1}$
}

\author{
Michael Gochfeld ${ }^{2}$

\section{INTRODUCTION}

Among traditional welcomes, the visitor to El Morro Castle in Old San Juan is greeted today by the raucous cries and flashing green plumage of the monk parakeet (Myiopsitta monachus). This parakeet is native to South America, breeding from Bolivia, Paraguay and Brazil (state of Mato Grosso and Rio Grande do Sul) through Uruguay south to the Río Negro of Argentina on the northern edge of Patagonia (6). These parakeets in Puerto Rico represent one of the many ectopic populations of parrots which have become established recently in various parts of the United States after removal of the ban on importation of psittacine birds (macaws, parrots, parakeets, cockatoos, etc.). Monk parakeets appear to be thriving in the wild in Puerto Rico and in several areas of the United States: northeastern, northcentral and southern states. The birds which make up these populations have most likely escaped either during shipment to pet dealers or from homes. Banks (3) noted that in 1968 alone 11,000 monk parakeets and about 50,000 other psittacine birds were imported legally into the United States.

In Puerto Rico, where the native Puerto Rican parrot (Amazona vittata) will almost certainly become extinct soon $(10,16)$, it may appear desirable to replace it with an exotic psittacine species. Regrettably, the arrival of monk parakeets is at best a mixed blessing. It seems likely that the birds will thrive in Puerto Rico, and there is no way to predict the growth-rate of the population. A population of these parakeets on an island with a heavily agrarian economy could become a serious economic hazard.

1 Manuscript submitted to Editorial Board May 3, 1972.

${ }^{2}$ Associate in Environmental Medicine, Division of Occupational and Environmental Health, Columbia University School of Public Health, New York, N. Y., and Department of Ornithology, American Museum of Natural History, New York, N. Y. Many individuals aided the author in countless ways during his field work in Argentina and Puerto Rico. The author acknowledges chiefly the countless favors of Sr. Francisco Nazar of Estancia La Saudade, Argentina. The information and opinions of Mr. John Bull, American Museum of Natural History, New York, who has been studying the spread of the Monk Parakeet in the northeastern United States, and of Dr. Philip S. Humphrey, University of Kansas, have been very useful. Field work in Argentina was supported by grants from the Frank M. Chapman Memorial Fund. 
In this report I discuss my moderate field experience with the monk parakeet in Argentina and New York, and information is provided derived from numerous interviews with agriculturalists and farm owners. This information causes me to be concerned with the uncritical attitude of the many individuals who are inclined to be tolerant of the introduction of this and other species of exotic wildlife into new environments. I hope this information will assist those responsible for evaluating the economic and aesthetic values of the monk parakeet.

\section{DESCIRIPTION OF THE FORMS}

Monk parakeets average 15 inches in length and are basically leaf-green on the head, wings, and back. The forehead and crown are pale grey. The upper wing coverts are blackish, and the remiges (primaries and secondaries) have blue or blue-green outer webs. This blue color is quite conspicuous in flight. In the field, the birds appear uniformly pale grey below. Close examination, however, reveals the presence of narrow white bars on the breast, formed by the white tips of the grey breast feathers. The abdomen is yellowish-green or dingy green, and the distal portion of the abdomen and undertail coverts are pale leaf green. The tail appears green or bluegreen, and the bill is yellowish.

Peters (15) recognized four subspecies of $M$. monachus, and because it is desirable to trace the origins of the new parakeet populations, a brief account of the distribution and plumage differences of the four is presented.

$M . m$. luchsi is of local distribution in Bolivia, and is the most distinctive and least known of the four. It has a pale, almost white crown, lacks any suggestion of white bars on the breast, and has the yellowest abdomen.

M. m. cotorra occurs in southeastern Bolivia, southwestern Brazil, Uruguay, and the chaco of Paraguay and northern Argentina. This subspecies has the grey breast blending into the dingy olivish abdomen.

$M$. m. calita occupies western Argentina, generally in semiarid country, and is the palest below.

M. m. monachus occupies eastern Argentina, generally in more humid country than the last. It is the largest and most robust of the four.

The different subspecies occupy different environments, that is subtropical vs. temperate, and semiarid vs. semihumid, and presumably they have different physiologic and ecologic adaptations. Regrettably no detailed field studies of any of them have been made.

Field identification of the subspecies of birds is a most uncertain process, because the subtle differences characterizing them usually are apparent only when the bird is held in the hand. Moreover, plumage characters are subject to individual variation in any population as well as to seasonal variation. Although it is impossible to be certain of the subspecies present 
in Puerto Rico, I did make careful observations on the parakeets at El Morro. My notes are detailed sufficiently to indicate that they are definitely not $M . m$. luschi but most likely $M . m$. monachus, which occupies Buenos Aires Province, and a likely candidate for exportation from Argentina.

\section{LITERATURE REVIEW ON BREEDING BIOLOGY}

Of some 315 species of parrots in the world, the monk parakeet is unique in its nesting habits. All other species, for which the nest is known, utilize holes or burrows for nesting purposes. The monk parakeet builds a bulky nest of sticks. It is a communal species. Several pairs participate in building a single large structure in which each pair has its own nest cavity. These structures are shared occasionally by other species of birds and animals. The size of some of these nests may reach 6 feet by 10 feet. The weight of such massive structures will occasionally break the supporting branches. In South America, most nests are reported to be on trees, although I have observed nests of these parakeets on utility poles where trees were not available. On the relatively treeless pampas, most nests are built in the trees in the artificial plantations surrounding private estancias $(7,8,14,17)$. Most nests in New York are placed on buildings or lamp poles.

In the south temperate zone, new nests are begun at the start of the breeding season in October and November but many are used for years and repaired annually. Although some of the birds disperse after the breeding period, a few usually remain near the nest site throughout the year. In South America, four to 12 pairs share the same nest structure. The two active nests I observed in Puerto Rico had three and four pairs, while two to four pairs is the usual number in the New York area. It is still uncertain as to what extent the species can adjust its breeding schedule to the northern hemisphere. Birds which arrived in New York began nesting in September and October, and continued their attempts to do so through the winter. A single young bird was raised eventually in the spring of 1971. In a tropical region, however, such adjustments are clearly less critical for survival of an exotic species.

The economic impact of ectopic populations of these parakects is dependent largely on the rate of growth of the population. Although their nests are conspicuous, little is known of their natural reproductive capacity. Clutch sizes varying from five to eight eggs have been reported $(\$, 14)$.

\section{FEEDING HABITS OF THE MONK PARAKEET}

Wherever I went in Argentina I heard this parakeet described as "una plaga nacional." The gregarious habit of the populations and their tolerance of man are usually characterized in vivid and dramatic descrip- 
tions of crop destruction, referring to their visitations to fields of rice, corn, wheat and a variety of fruits. Some of the reports probably were contrived or exaggerated. Although I did not see huge flocks at work in the fields, I have no reason to doubt that at least some of the numerous stories of farmers and ornithologists are true.

There has been no published detailed study of the feeding behavior of the monk parakeet. Gibson (S) reported them as devouring fruit, often taking only one or two pecks out of each fruit and destroying much greater quantities than consumed. Friedmann (7) noted that stomachs of specimens contained a variety of legume seeds, but he did not mention whether these included cultivated species. Wetmore (17) reported the birds feeding on old sweet potatocs and noted they also consumed large quantities of corn. In Paraguay, the birds also are reported to feed on palm fruits. The broad food spectrum of this parakeet is confirmed by reports from the New York area where they have been observed eating a wide variety of fruits (including particularly Malus spp. and Prunus spp.), bananas, many kinds of seed, acorns (fruits of Quercus spp.), and even bread (4).

\section{NATURAL AND ARTIFICIAL CONTROLS}

Natural populations of organisms are controlled by the availability of critical resources, by predation, parasites, disease, and by physical factors in the environment. For birds, food and nesting sites are very often critical factors. It is apparent that the broad diet tolerance of the monk parakeet ensures that it will be able to utilize a great variety of different food sources and therefore will be able to adjust readily to new habitats. Species of birds which nest in holes or other cavities often have their population size limited by the number of sites available. Almost all psittacine species nest in holes and, for example, nest sites have been found to be one of the factors limiting the population of the Puerto Rican parrot (10). The monk parakeet is not a hole-nester, however, and thus is immune to this limiting factor. Moreover, it has proven quite adaptable in utilizing a variety of substrates for building nests. In Argentina, for example, where the government has encouraged nest-destruction, this parakeet switched from traditional low tree sites (such as Celtis tala) to higher ones on introduced Eucalyplus trees, $(7,9)$ where their nests are often found 70 fect or more above ground.

Temperature and moisture are the two most important among the physical environmental factors affecting bird populations and their distribution. The monk parakeet thrives from hot, essentially tropical regions to temperate areas of the Southern Hemisphere, although individual birds or local populations are limited considerably in the environment to which they are exposed. Thus, monk parakeets do not appear to be very sensitive 
to temperature in terms of distribution. The environment in which it occurs normally varies widely in rainfall, from mesic to xeric, but the bird does not appear to occur in zones which are humid. Thus one would not expect to find the monk parakect established in the Luquillo Forest area of Puerto Rico. There are many areas in Puerto Rico, however, which match quite well the climate to which natural populations of monk parakect are exposed in both temperature and humidity.

If natural factors are not likely to interfere with the growth and spread of monk parakeet populations in Puerto Rico, agriculturalists must be concerned with artificial control measures. It is important therefore to consider control measures utilized elsewhere. The Argentine government offered bounties for the parakeets, encouraged some hunting, and thereby severely decreased the population of another Argentine parrot. But the monk parakeet seems to thrive in the presence of man and apparently tolerates a considerable amount of hunting. Destruction of the conspicuous nests would seem to be a more feasable approach to control. Nest destruction has not worked well in Argentina where many areas are very sparsely settled and where the parakeets can disperse, but this may be an effective form of control in Puerto Rico where space and habitats appear to be more limited.

\section{PARROTS AND VIRUSES}

For many years, fear of spreading the infectious agent of psittacosis accounted for a ban on the importation of psittacine birds. Psittacosis, however, has become quite an uncommon disease; at least it is rarely diagnosed. In New York State (excluding New York City), only four cases were reported in 1970-71 (5). Certainly many more cases must pass undiagnosed for it requires a considerable degree of clinical suspicion to look for psittacosis, but we can at least be confident that there is little mortality attributable to psittacosis today. It would be regrettable, indeed, if a resurgence of this disease occurred after liberalizing import regulations, despite the availability of antibiotics effective against the disease.

Recently, however, the importation of Newcastle disease virus into West Germany was traced on three occasions to exotic parrots imported from South America and Africa (13). Outbreaks of Newcastle disease in Florida and in some of Lesser Antillean Islands in 1972 were associated with the importation of presumably infected psittacines. This underscores the important fact that reservoir and vector potentials of wild birds and other wildlife must be more clearly understood, particularly if importation is to be contemplated. In the United States fear of Newcastle disease resulted in a temporary ban on all bird importations in 1972-73. 


\section{ECOLOGICAL IMPLICATIONS OF INTRODUCED WILDLIFE}

This brief summary of the biology of the monk parakeet clearly demonstrates the need for vigilance in determining the status and biological potential of ectopic populations. It establishes that the monk parakeet is highly adaptable, tolerant of man, tolerant of a wide variety of climates and food sources and able to utilize many different substrates for nesting purposes. If populations become established in Puerto Rico and elsewhere, there is considerable risk that the birds may become a serious nuisance if not a financial threat. A heavily populated island such as Puerto Rico offers a moderate climate as well as a substantial variety of foods and habitats. Although there are a sufficient number of people on the island to locate and destroy the colonies if that should become a governmental policy, it would be much more efficient to control the parakeets now while the population is limited

The Guianian blue-winged parrotlet (Forpus passerinus) was introduced into Jamacia where it has become extremely successful. Many Jamaican farmers consider all parrots as pests and destroy them whenever possible. The populations of the three native Jamaica parrots thus have declined, but the parrotlet continues to thrive and gathers in large flocks to feed on various crops (personal observation). The story of the parrotlet on Jamaica is indeed an instructive lesson.

\section{RISKS OF IMPORTING EXOTIC ORGANISMS}

For centuries, by accident or design, men have moved various plants and animals into new habitats. Many of these introductions were useful but it is probable that greater numbers of real or potential disease or pest organisms have be introduced into almost every country (12). The often rapid establishment of possibly viable populations of detrimental plants and animals is a source of great concern to medicine and agriculture, as well as to some ecologists $(2,11,12,18)$. There is great merit to the proposition that it is unethical to establish or tolerate the establishment of ectopic populations of exotic creatures without previous adequate study. However, no one at present seems able to define "adequate study." Introductions of biological entities are potentially dangerous whether intentional or not. The destructive capacity of the monk parakeet has been detailed above, but we have essentially no information on the potential risk associated with feral populations of the Hispaniolan parrot (Amazona ventralis), the yellow-headed parrot ( $A$. ochrocephala), or the canary-winged parakeet (Brotogeris versicolorous), also established in Puerto Rico. The biologies of these bird species also need to be investigated in relation to their economic potential. 
At present, there is sufficient information to establish these three elementary guidelines:

1. No biological entity, animal or plant, should be imported into an area in which it did not previously exist until adequate safeguards are taken to assure that it will not escape, and until the risks associated with a resulting feral population are known.

2. Deliberate introduction and release of exotic biological entities for recreational purposes should not be tolerated. If introduced for economic purposes, the risks should be clearly understood prior to introduction and release; both the risks of probable importation of disease, as well as the ecological consequences of a resulting feral population.

3. Once importation is authorized, a system must be available immediately to control the importation, to assure that the entities will not be diverted (willfully or accidentally) to other purposes, and to monitor the introduced entity continuously for unanticipated consequences.

4. If a feral population of an exotic entity is found to be harmful despite careful preparation and control, immediate steps should be taken to eradicate it. Such steps should be specific, with minimal impact on neutral or beneficial organisms. When doubt exists, particularly during early stages of the establishment of a feral population, overcontrol rather than undercontrol should be preferred.

These four considerations cannot furnish a guarantee for freedom from harmful consequences of the establishment of an exotic species but they will be least ameliorate the situation.

The differences between taking immediate versus delayed action against potential pests in recently infested areas has been discussed by Popham and Hall (18). Their studies indicate delay usually is the less desirable alternative. Delay enables the pest population in most instances to move past the lag phase of growth into the logarithmic phase and may prevent subsequent eradication. The phrase "further research is needed" must never become a euphemism for failure to act.

\section{CONCLUSION}

The monk parakeet is an attractive, interesting, and apparently adaptable species. One or more of its subspecies appears destined to become established in many parts of North America. Our knowledge of its reproductive behavior indicates that it is likely to thrive in a wide variety of habitats, and its known dietary tolerance shows adequate evidence to label it a potential agricultural pest. It is ironic that in Puerto Rico this prakeet should apparently be so successful where the native parrot is on the verge of extinction and the green parakeet (Aratinga chloroptera maugei) has been extinct for a century. 
Two alternatives apparently face officials in Puerto Rico. The first would be to move immediately to locate and exterminate colonies of the parakeet as a potential pest. The second would be to locate and document nest sites and at the same time conduct careful investigations of breeding biology, population growth, food habits, and ecological adaptations. This would permit early recognition of future problems, and accurate knowledge of nesting sites would enable swift control or elimination. The first of these alternatives is favored.

The above evidence indicates that the monk parakeet is an agricultural pest in its natural range. Dr. Alexander Wetmore, one of the world's leading authorities on Neotropical birds and the birds of Puerto Rico, pointed out long ago (17) the hazards of monk parakeets to agriculture in Argentina. Recently, he indicated (personal communication, May, 1973) that this species poses a threat to the agriculture of Puerto Rico unless steps are taken to eliminate it there. My opinions and conclusions, based on personal field experience, coincide with those of Dr. Wetmore. Dr. Philip S. Humphrey, Director, Natural History Museum, Kansas University, who also investigated this parakeet in Argentina, also has arrived at this conclusion (personal communication).

If parrots are desirable in Puerto Rico, full energy should be devoted to preserving the endangered native species of which probably 20 or fewer birds presently exist in the wild (10).

\section{SUMMARY}

Ectopic populations of the monk parakeet (Myiopsitta monachus), derived from birds imported for the pet trade, now exist in Puerto Rico, the New York metropolitan area, and other localities in North America. This parakeet normally occupies southern South America where it is tolerant of a wide variety of climates, habitats and food sources. It has succeeded in breeding in the northern hemisphere. The growth potential of current populations here is unknown. A review of its feeding habits provide proof that it is a potential agricultural pest. It is most undesirable to introduce exotic species to new areas. Even when a biological entity has been studied thoroughly and appears destined to become beneficial, unforeseen detrimental consequences may occur upon its establishment in a new environment. It is thus important to study the new feral populations of the parakeet in Puerto Rico very closely if eradication is not planned, but enough evidence exists to indicate that its extermination is desirable.

\section{RESUMEN}

Poblaciones ectópicas del periquito Myiopsitta monachus, derivadas de aves importadas para el mercado de animales caseros se encuentran actualmente en Puerto 
Rico, la zona metropolitana de Nueva York y otras localidades. La especie normalmente habita en la parte meridional de Sur América, y ha dado pruebas de ser tolerante a una gran variedad de climas, hábitats y fuentes de alimento. Se ha reproducido con éxito en el hemisferio norte. El potencial de crecimiento de las poblaciones actuales se desconoce. Un examen de sus hábitos alimenticios demuestra que la especie es potencialmente dañina para la agricultura. Es indeseable permitir que especies exóticas se introduzcan a una nueva área. Aun cuando la especie se haya estudiado bien y parezca ser beneficiosa, es posible no prever consecuencias dañosas cuando se establece en un nuevo ambiente. Es importante estudiar cuidadosamente las nuevas poblaciones de periquitos si éstas no se han de exterminar. Sin embargo, hay suficientes pruebas para persuadirnos a creer que la exterminación es aconsejable.

\section{LITERATURE CITED}

1. Anonymous, Exotics, handle with care, Wildlife Review 5(8): 4-7, 1970.

2. Anonymous, Symposium on introduction of exotic animals: ecologic and sociologic considerations, Caesar Kleberg Research Program of Texas A. and M., 1968.

3. Banks, R. C., Birds imported into the United States in 1968, U.S. Dept. Interior, Bur. Sport Fish. and Wildlife, Special Scient. Rep.-Wildlife, No. 136., 1970.

4. Bull, J., Monk parakeets in the New York City region, Linnaean News-Letter, 25(1): 1-2, 1971.

5. Communicable Disease Newsletter, N.Y. S. Dept. Health, Vol. 2(4), 1971.

6. de Schauensee, R. M., The species of birds of South America with their distribution, Livingston Publ. Co., $\mathrm{Pa} ., 1966$.

7. Friedmann, H., Notes on some Argentina birds, Bull. Mus. Comp. Zool. 58: 139236., 1927.

8. Gibson, E., Ornithological notes from the neighbourhood of Cape San Antonio, Buenos Ayres, Ibis, ser. 4, 4(1): 3-6, 1880.

9. Hudson, W. H., Birds of La Plata, J. M. Dent and Sons, Ltd., London, Eng., pp. 30-3, 1920.

10. Kepler, C. B., The Puerto Rican parrot, in "A Tropical Rain Forest", ed. by H. T. Odum, U.S. A. E. C., pp. E 186-8, 1970

11. Lachner, E. A., Robins, C. R., and Courtenay, Jr., W. R., Fishes and other aquatic organisms introduced into North America, Smiths. Contrib. Zool. 59(1): 1-29, 1970.

12. Laycock, G., The Alien animals, Natural History Press, New York, N. Y., 1966.

13. Luthgen, W., and Wachendorfe, G., Newcastle disease in freshly imported large parrots, (abstract), Avicult. Mag. 77 (2): 82, 1971.

14. Naumburg, E. M. B., The birds of Matto Grosso, Brazil, Bull. Amer. Mus. Nat. Hist. 60: 126-9, 1930.

15. Peters, J. L., Check-list of birds of the World, Harvard Univ. Press, Cambridge, Mass., vol., 3, 1937.

16. Rodriguez-Vidal, J. A., Puerto Rican Parrot (Amazona vitlata vitlata) study, Dept. of Agr. and Comm. of Puerto Rico, Monogr. No. 1: 1-15, 1959.

17. Wetmore, A. Observations on the birds of Argentina, Paraguay, Uruguay, and Chile, Bull. U.S. Natl. Mus. 133: 194-6, 1926.

18. Popham, W. L. and Hall, David G., Insect eradication programs. Annual Rev. Entomol. 3: 335-354, 1958. 